\title{
GRAPHIC EXPRESSION AS SUPPORT OF CRITICAL THINKING IN NATURAL SCIENCES SUBJECTS
}

\section{[GRAFICKE VYJADROVANIE AKO PODPORA KRITICKEHO MYSLENIA V PRIRODOVEDNYCH PREDMETOCH]}

\author{
Radka Mala - Zita Jenisova
}

doi: 10.18355/PG.2019.8.1.13

\begin{abstract}
Nowadays, full of digitized information, it is important to orientate, evaluate and interpret symbols, charts, schemes that are part of our lives. The paper is focused on approximation of graphic expression as a part of development of critical thinking among students in science subjects. The graph and its understanding are irreplaceable in science and hence chemistry. Part of the presented paper is a demonstration of tasks focused on graphic expression, its evaluation and also a description of possible causes of incorrect answers in students.
\end{abstract}

\section{Key words}

critical thinking, graphical skill, graph of function, symbol

Anotácia

V dnešnej dobe plnej digitalizovaných informácií je dôležité správne sa orientovat', vyhodnocovat' a interpretovat' symboly, grafy, schémy, ktoré sú súčast'ou nášho života. Príspevok je zameraný na priblíženie grafického vyjadrovania ako súčast' rozvoja kritického myslenia u študentov v prírodovedných predmetoch. Graf a jeho pochopenie má nezastupitel'né miesto v prírodovedných predmetoch a teda aj chémie. Súčast'ou prezentovaného príspevku je ukážka úloh zameraných na grafické vyjadrovanie, jeho vyhodnotenie a tiež popis možných príčin nesprávnych odpovedí u študentov.

\section{Kl'účové slová}

Kritické myslenie, grafická zručnost', graf funkcie, symbol

\section{1 Úvod}

V rozmedzí rokov 2003 až 2012 prebehlo aj na Slovensku medzinárodné testovanie OECD PISA u 15-ročných žiakov v oblasti čitatel'skej, prírodovednej a matematickej gramotnosti. Výsledky dosiahnuté slovenskými žiakmi v uvedených gramotnostiach boli pri testovaniach rôzne, no vždy bud' na úrovni priemeru alebo podpriemeru krajín OECD. Často sa poukazuje na problémy spojené s aplikáciou konkrétnych vedomostí, ich spájaním a samozrejme s grafickým vyjadrovaním, ktoré priamo, či nepriamo súvisí s čítaním grafov a ich funkciami, úpravou a dopín̆aním do tabuliek. Je zrejmá nízka úroveň schopnosti žiakov prepájat' si informácie spojené 
s integráciou medzipredmetových vzt’ahov matematika, fyzika, informatika, chémia.

Grafickým vyjadrovaním, alebo grafickými zručnost’ami sa zaoberajú viacerí autori (Tomková, Tirpáková, 2009, Fajnorová, 2012, Horváthová, Zelenický, 2009), ktorí sa zamerali najmä na predmety technická výchova, matematika, či fyzika. Pedagogickým experimentom overovali, či je možné rozvíjat' grafické zručnosti žiakov aplikovaním technických úloh v tomto predmete. Po realizovaní testov a vyhodnotení štatistickými metódami bolo dokázané, že úroveň grafických zručností žiakov sa zvyšuje aplikovaním navrhnutého vyučovacieho modelu technickej výchovy.

Problematika grafického vyjadrovania je úzko spätá práve s prírodovednými vyučovacími predmetmi, ktorých základ tvorí práve experiment. Pri realizácii pokusov sa často namerané hodnoty musia zaznamenávat' a teda musí byt' zvolený nástroj na ich interpretovanie. Je zrejmé, že žiaci by mali mat' dobré základy $\mathrm{v}$ oblasti grafu funkcie $\mathrm{z}$ matematiky a vedeli vyjadrovat' rôzne závislosti medzi veličinami.

\section{Kritické myslenie - dôveruj, ale preveruj!}

Slovo „kritický“ má korene v gréckom slove „krinein“, čo znamená rozlišovat' alebo posudzovat'. Je vel'mi podstatné si uvedomit', že pojem kritické myslenie sa nevzt'ahuje na kritiku v takom zmysle, v akom sa s n̆ou stretávame $\mathrm{v}$ bežnom živote. Neznamená to, že budeme niečo neustále vnímat' ako chybné alebo všetko kritizovat' a vidiet' v negatívnom svetle (Vranaiová, 2014). Jednou z najdôležitejších kompetencií človeka je práve kritické myslenie. Definovat' by sme ho mohli ako určitý postoj voči konkrétnym názorom, ku konkrétnym situáciám, k svetu samotnému. Ďalej ho možno chápat' ako schopnost', ktorá je predpokladom k opatrnosti, obozretnosti pri využívaní, vyhl'adávaní aj interpretácii informácií. Kriticky mysliaci človek sa v podstate len riadi múdrym príslovím - Dôveruj, ale preveruj.

Ak posudzujeme niekoho názor alebo postoj, neznamená to, že danému človeku nedôverujeme, skôr ide o snahu dôkladnejšie a hlbšie objavit' a pochopit' súvislosti medzi teóriou a informáciami, ktoré $\mathrm{k}$ nám od interpreta prichádzajú. Teda ak kriticky myslíme, neprijímame len pasívne a povrchne informácie, ale zamýšl'ame sa nad nimi a posudzujeme ich (www.eduworld.sk).

V súčasnosti sme obklopení vel'kým množstvom informácií a je obzvlášt' dôležité denne uplatňovat' kritické myslenie. Človek s kritickým myslením nie je spokojný s nepatrným množstvom informácií, ale skúma d'alej, snaží sa analyzovat' rôzne pohl'ady na vec, informácie sa snaží overovat', dáva prednost' objektivite pred subjektivitou, rozlišuje medzi názormi a faktami, nedôveruje nejasným a nejednoznačným pojmom (Čeretková a kol., 2017). Obraz o svete si vytvorí sám na základe zaujatia vlastného stanoviska, nepreberá ho od druhých. Človek rozvíjajúci kritické myslenie vie rozhodnút' a posúdit', čo je správne a čo nie je správne (Turek, 2003).

\subsection{Zručnosti a dispozície kritického myslenia}


S početnými a premenlivými popismi kritického myslenia boli odborníci nútení jasne a konkrétne definovat' kritické myslenie, ak ho chceme systematicky posudzovat' a podporovat' v kontexte vzdelávania (Velmovská, 2012). V roku 1990 bol vedúcim výskumníkom na kritické myslenie, Peter Facione, ktorý viedol skupinu odborných filozofov pri definovaní kritického myslenia pomocou metódy Delphi. Odborníci predložili individuálne definície kritického myslenia, ktoré analyzovali a doladili, kým nedosiahli zhodnú definíciu. Dospeli k záveru, že myslenie sa skladá $\mathrm{z}$ dvoch schopností: zručností a dispozícií, a že nemôžeme očakávat', že osoba, ktorá má schopnosti kritického myslenia, ich jednoducho použije, táto osoba musí byt' tiež naklonená k praktizovaniu zručností.

Definícia podla Delphi zahŕňala šest' zručností kritického myslenia a sedem dispozícií kritického myslenia. Zručnosti sú interpretácia, analýza, hodnotenie, dedukcia, vysvetlenie a samoregulácia. Kriticky mysliaci človek bude interpretovat', analyzovat', hodnotit' a vyvodzovat' závery z informácií na vytvorenie úsudku založeného na dôkazoch. Okrem toho kriticky mysliaci človek vie vysvetlit' dôkazy, teórie, koncepty, metódy, kritériá alebo kontexty, ktoré podporujú daný úsudok. Zhromaždením a hodnotením úsudku sa kriticky mysliaci človek môže rozhodnút', v čo verit' alebo ako postupovat' v danej situácii. Niektorí vedci nazývajú tento proces analytické zdôvodnenie. Tento typ zdôvodnenia zahŕn̆a rozdelenie konceptu do rôznych častí a analýzu toho, ako sú časti vzájomne prepojené (Feszterová, 2015). Preto analytické zdôvodnenie považujeme za kognitívny proces prichádzania $\mathrm{k}$ niečomu, čomu veríme prostredníctvom odôvodneného procesu skúmaných častí tohto presvedčenia. Ak osoba používa analytické zdôvodnenie, osoba používa zručnosti kritického myslenia.

Dispozícia kritického myslenia je charakterizovaná ako osobnostná črta, dispozícia naznačuje ako by sa človek postavil $\mathrm{k}$ problém a použil zdôvodnenie na jeho vyriešenie. Osoba so silnými dispozíciami kritického myslenia má vysokú vnútornú motiváciu robit' rozhodnutia, riešit' problémy alebo hodnotit myšlienky kritickým myslením. Experti z Delphi zistili sedem dispozícií kritického myslenia: zvedavost', systematickost', hladanie pravdy, objektívnost', sebadôvera, analytickost' a zrelost'.

Tieto dispozície pochádzajú zo štýlu učenia sa človeka, prístupu $\mathrm{k}$ rozporuplným názorom a pozornosti pri rozhodovaní. Zvedavost' popisuje všeobecnú túžbu jednotlivca učit' sa. Systematickost' je tendencia klást' otázky organizovaným a sústredeným spôsobom. Hl’adanie pravdy popisuje snahu jednotlivca o čo najpresnejšie poznanie - napriek zisteniam, ktoré nepodporujú vlastné názory alebo záujmy - a neustále prehodnocovanie informácií, pričom jednotlivec zostáva poctivý a objektívny počas celého úsilia. Objektívnost', spoločný faktor vo väčšine definícií kritického myslenia, vyjadruje toleranciu názorov jednotlivcov odlišných od ich vlastných a citlivost' voči vlastnej zaujatosti. Sebadôvera opisuje, kol'ko dôvery dávajú jednotlivci do svojho vlastného logického procesu, ked' prichádzajú $\mathrm{k}$ úsudku a ich dôveru $\mathrm{v}$ seba, aby viedli ostatných $\mathrm{k}$ riešeniu. Analytickost' je charakterizovaná tým, ako jednotlivci použivajú úvahy a dôkazy k navrhovanému riešeniu, zatial' čo predvídajú potenciálne t’ažkosti a zostávajú ostražití. Zrelost' je dispozícia očakávania blížiacich sa problémov, 
uvedomovanie si ich zložitej štruktúry a toho, že viaceré riešenia môžu byt' pravdepodobné, hoci neisté, v závislosti od kontextu a podporných dôkazov (Kostura Polk, 2018).

\subsection{Symbol ako dorozumievací prostriedok}

V dnešnej dobe, v ktorej žijeme, sme obklopení masovo-komunikačnými prostriedkami, ktorými sme chtiac, či nechtiac ovplyvňovaní. Sme ich nútení čítat', porozumiet' im, pracovat' s nimi a v konečnom dôsledku ich častokrát musíme interpretovat'. Aby sme porozumeli informáciám, ktoré sú určené pre šrokú verejnost', pre rôzne národnosti, zaviedli sa symboly, ktoré nám ulahčujú orientáciu aj v cudzom prostredí.

V rôznych oblastiach života sa stále intenzívnejšie využívajú abstraktné dorozumievacie prostriedky - symboly, modely, schémy, grafy, ktoré boli donedávna charakteristické najmä pre matematiku. Operácie so symbolmi predstavujú názornost' vyššieho typu, umožňujú vyjadrovat' zložité myšlienkové útvary prehl'adne, do systémov, v ktorých sú symboly navzájom pospájané vzt’ahmi. Na porozumenie a použivanie symbolického jazyka má žiaka vhodným spôsobom pripravit' škola. Významnú úlohu $v$ sústave predmetov plnia prírodovedné predmety, ktoré pre svoj experimentálny charakter umožňujú žiakom konkretizovat' symbolický jazyk a spájat' ho $\mathrm{s}$ dejmi z denného života. $Z$ toho dôvodu boli do učebných osnov predmetov pre základnú školu a gymnázia zaradené požiadavky na rozvoj schopností žiakov porozumiet' a používat' symbolický jazyk, najmä graf funkcie a tým zlepšovat' grafické vyjadrovanie študentov.

\subsection{Graf funkcie}

Funkcia $\mathrm{v}$ matematike patrí $\mathrm{k}$ najvýznamnejším pojmom a používa sa $v$ rôznych významoch. Podl'a J. Kurzweila, je „,funkcia f určená množinou $\mathrm{D}(\mathrm{f})$ a vieme, čo znamená $\mathrm{f}(\mathrm{x})$ - hodnota funkcie $\mathrm{f} \mathrm{v}$ bode $\mathrm{x}$ pre každé $\mathrm{x} \in$ $D(f)$. Pritom D(f) sa nazýva definičný obor funkcie fa môže byt' l'ubovol'nou množinou. Hodnota funkcie $\mathrm{f} v$ bode $\mathrm{x}$ je reálne číslo, komplexné číslo, alebo prvok daného vektorového priestoru“".

Iný prístup k pojmu funkcie je možný prostredníctvom pojmu zobrazenia. Pod pojmom zobrazenie rozumieme zobrazenie množiny do množiny, plochy do plochy, grupy do grupy, množiny do systému grúp, resp. zobrazenie vektorového priestoru do vektorového priestoru. Množinová terminológia však pri objasňovaní pojmu funkcie nie je vždy prínosom pre jej pochopenie. Pre školskú matematiku je podstatnejšie zdôraznit', že pojem funkcie je matematickým vyjadrením závislosti. Na základných a stredných školách je vhodné vychádzat' pri zavádzaní pojmu funkcia $\mathrm{z}$ intuitívnej predstavy priradenia, predpisu (Kurzweil, 1985).

Ku grafom funkcií (lineárna, exponenciálna alebo kvadratická) sa dajú priradit’ určité závislosti z reálneho života:

1. Zaznamenávanie fyzikálnej veličiny (napr. teplota, objem tlak ) za určitý zvolený časový interval - predmet fyzika, chémia.

2. Závislost' výšky hladiny vo vodnej nádrži v závislosti na čase predmet fyzika. 
3. Rast mikroorganizmov (nárast počtu buniek) v závislosti od časupredmet biológia.

4. Závislost' uhla otočenia opticky aktívnej látky od hustoty - predmet chémia.

5. Závislost' absorbancie od koncentrácie - predmet chémia.

6. Šikmý vrh vo vzduchu, mechanické oscilátory - kmitanie - predmet fyzika.

\section{Empirický výskum}

Uskutočnili sme pilotné testovanie študentov pomocou krátkeho didaktického testu na predbežné zistenie úrovne ich grafického vyjadrovania - grafických zručností. V teste sme vytvorili 6 úloh na prepojenie poznatkov o grafe funkcie z predmetu matematika a spojili ich s vedomostami z predmetu chémia. Úlohy neboli zamerané len na graf funkcie, ale aj na porozumenie rôznych schém, náčrtov, obrázkov, na prácu s tabul'kou a čítanie grafov (Obr. $1)$.

Testu sa zúčastnilo 40 študentov, z toho 20 študentov bolo z Univerzity Konštantína Filozofa v Nitre (10 prvákov a 10 druhákov) študujúcich učitel'stvo chémie v kombinácii. Ďalších 20 študentov bolo z Piaristického gymnázia sv. Jozefa Kalazanského v Nitre, z toho 10 študentov bolo v tret'om ročníku (resp. septima) a 10 študentov bolo vo štvrtom ročníku (resp. oktáva) 4-ročného (resp. 8-ročného) štúdia. 


\section{Grafické ryjadrovanie}

pohlasie:

ročnik:

iksola:

1. Ako bude vyzerat graf chemickej reakcie (chemického deja), ak sme namerali nasledujuce údaje $v$ taburke:

\begin{tabular}{|c|c|c|c|c|c|c|}
\hline $\mathbf{x}$ & -2 & -1 & 0 & 2 & 3 & 4 \\
\hline $\mathbf{y}$ & 6 & 4 & 2 & -2 & -4 & -6 \\
\hline
\end{tabular}

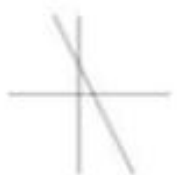

a)

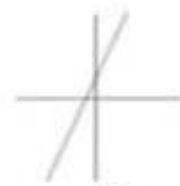

b)

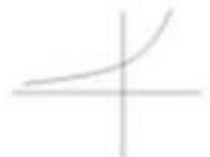

c)

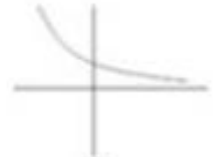

d)

2. Omačte, akú chemicku reakcit by mohla predatavovat nasledujuca schéma:

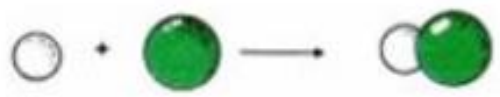

a) $\mathrm{H}+\mathrm{H} \rightarrow \mathrm{H}_{2}$

b) $\mathrm{Na}+\mathrm{OH} \rightarrow \mathrm{NaOH}$

c) $\mathrm{H}+\mathrm{Cl} \rightarrow \mathrm{HCl}$

3. Zakrúžkuj vodik na obrízku, ktorý predstaruje umiestnenie pred rovinou papiera.<smiles>C</smiles> 
4. Ozmačte graf, ktorý predstavuje priebeh chemickej reakcie za pritomnosti katalyzátora:

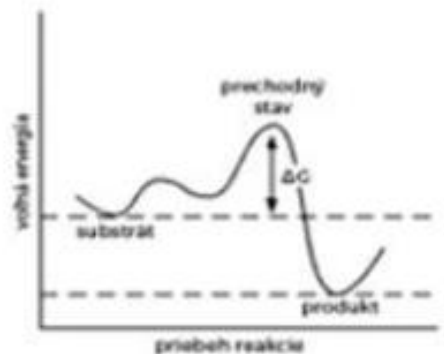

a)

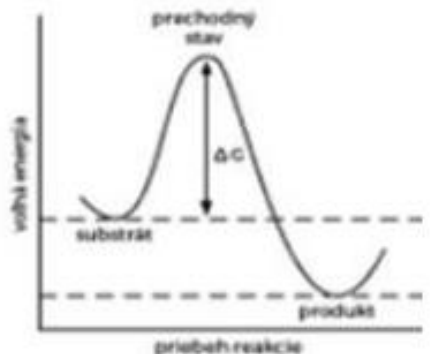

b)

5. Na zảklade obrázica (dvojatómovej molekisuly dusika) určite, kolko elektrónov má na valenčnej vrstve dusùv v atómovom stave.
a) 7
b) 8
c) 2
d) 5
e) 10
f) 6

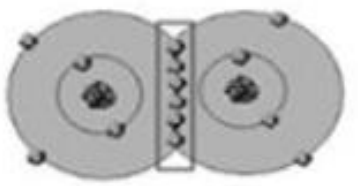

6. Priradte jednotlivé funkcie $\mathrm{k}$ správnym grafom:

\section{kvadratická funkcia lineima funkcia exponenciálna funkcial}
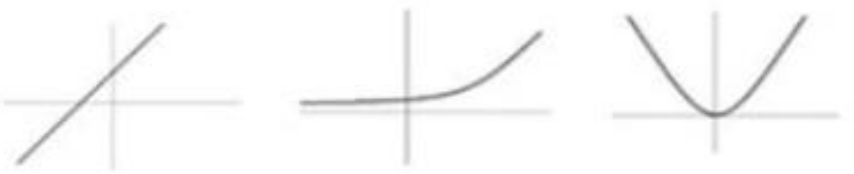

Obrázok 1. Didaktický test-grafické vyjadrovanie

Z uvedeného testu sme vybrali 2 úlohy, ktorých výsledky sme zaznamenali a vyhodnotili pomocou funkcie aritmetický priemer a následne interpretovali formou grafov. Zastúpenie správnych odpovedí sme vyjadrili v percentách.

\section{Výsledky a diskusia}

Štatisticky sme spracovali úlohu 1: Ako bude vyzerat' graf chemickej reakcie, ak sme namerali nasledujúce údaje $v$ tabul'ke? 


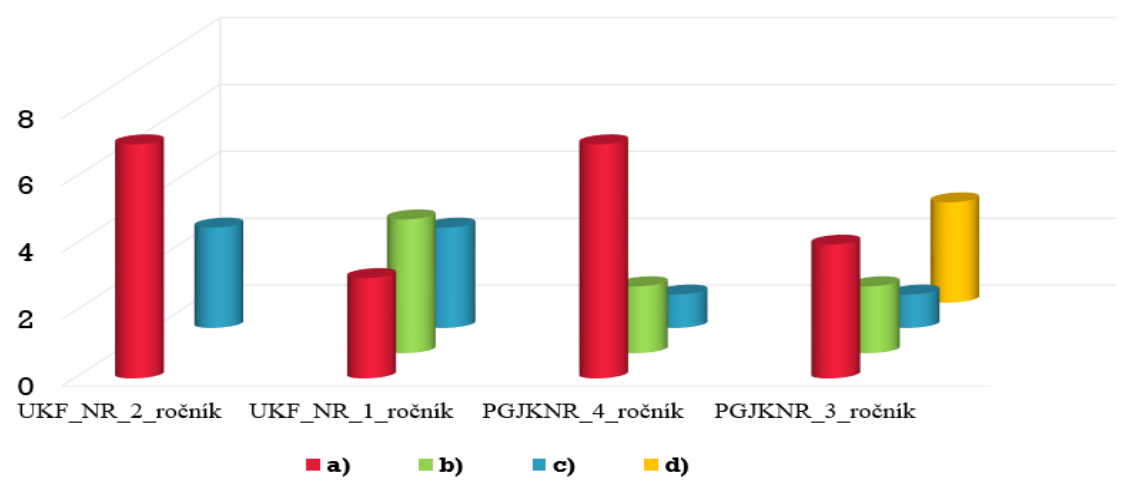

Obrázok 2. Počet odpovedí študentov za jednotlivé možnosti a) b) c) d) Na Obr. 2 si môžeme všimnút' počet odpovedí študentov z konkrétnych ročníkov a škôl za jednotlivé možnosti. Na Obr. 3 sa nachádza percentuálne zastúpenie jednotlivých odpovedí všetkých 40 študentov, ktorí sa zúčastnili testu. Ako je zrejmé z Obr. 2 väššina študentov označila správnu odpoved' „a)“, ale percentuálne zastúpenie tejto odpovede všetkých 40 študentov je podl'a Obr. 3 len 52,5\%. Môžeme teda predpokladat', že príčiny nesprávnych odpovedí u študentov mohli nastat' tým, že študenti nevedia, ktorý graf predstavuje ktorú funkciu, nepoznajú predpisy jednotlivých funkcií, ani grafy funkcií, nevedia riešit' sústavu dvoch rovníc s dvomi neznámymi a nemajú vedomosti o monotónnosti funkcie. To môže byt' dôsledok neschopnosti aplikovat' matematické vedomosti a zručnosti do praxe a navzájom ich prepájat'.

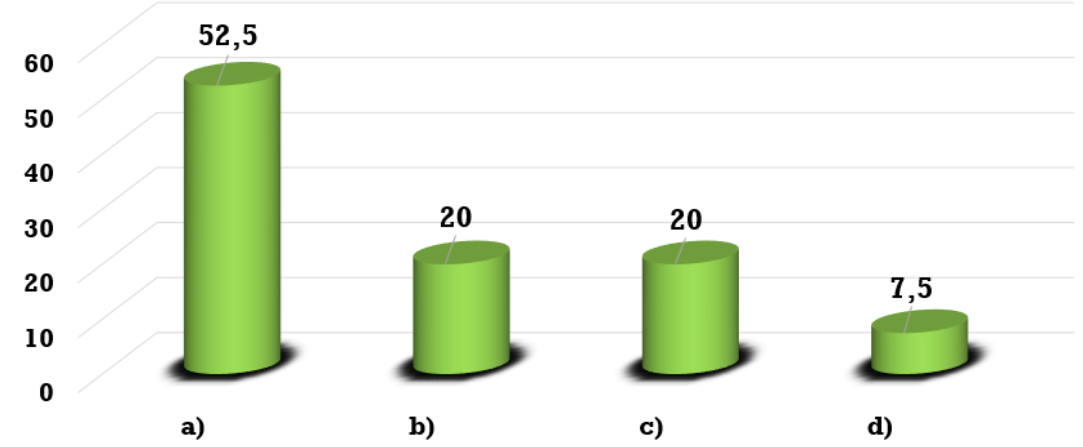

Obrázok 3. Percentuálne zastúpenie jednotlivých odpovedí študentov 
Ďalej vyberáme analýzu úlohy 5: Na základe obrázka (dvojatómovej molekuly dusika) určite, kol’ko elektrónov má na valenčnej vrstve dusík $v$ atómovom stave.

Na Obr. 4 je graf, ktorý znázorňuje počet odpovedí študentov z konkrétnych ročníkov a škôl za jednotlivé možnosti. Na Obr. 5 môžeme sledovat' percentuálne zastúpenie jednotlivých odpovedí všetkých 40 študentov.

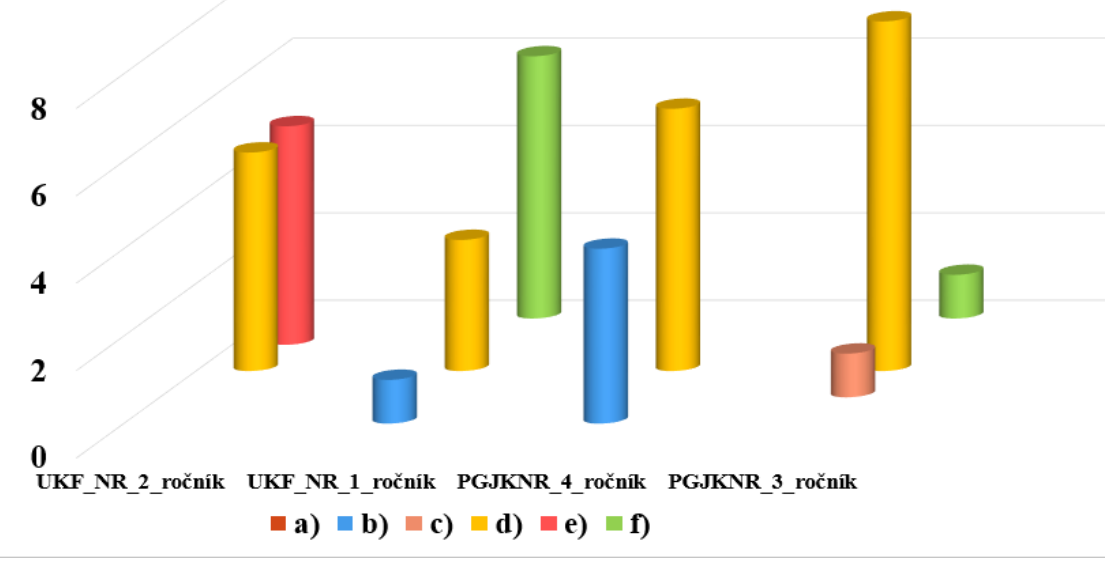

Obrázok 4. Počet odpovedí študentov za jednotlivé možnosti a) b) c)

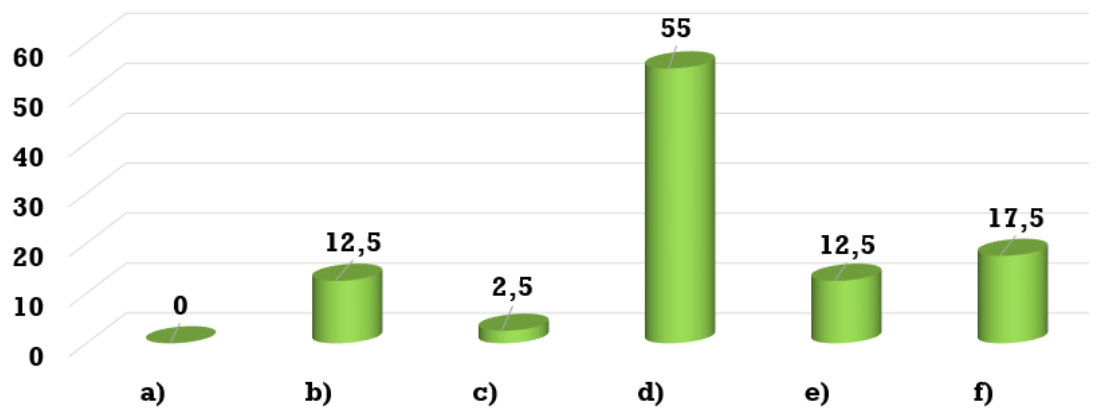

$$
\text { d) e)f) }
$$

Obrázok 5. Percentuálne zastúpenie jednotlivých odpovedí študentov

Z rozboru odpovedí vyplýva (Obr. 4), že až na študentov 1. ročníka UKF v Nitre odpovedali študenti ostatných škôl a ročníkov správne a označili teda odpoved” „d“ ako správne riešenie. Percentuálne zastúpenie tejto odpovede podl'a (Obr. 5) všetkých 40 študentov je znovu len 55\%, takže aj tu pozorujeme, že študenti nevedia správne interpretovat' obrázky - grafické znázornenie molekuly $\mathrm{N}_{2}$. Nesprávne odpovede u študentov mohli nastat' 
tým, že študenti nevedia, čo je to valenčná vrstva atómu, nepoznajú pojem atómový stav dusíka, lebo sa s podobným grafickým znázornením ešte nestretli a majú nezrovnalosti v pochopení princípu vzniku chemickej väzby.

\section{Záver}

Správne interpretovat' chemické schémy, vytvárat' grafy z tabuliek, pochopit' náčrt obrázkov si vyžaduje rozvíjat' kritické myslenie u študentov počas celého štúdia. Náš krátky didaktický test dokazuje, že dokonca študenti aj na vysokých školách majú nedostatočne rozvinuté kritické myslenie a s tým súvisiace grafické vyjadrovanie. Nie sú naučení riešit' praktické úlohy, a tým pádom nevedia vždy správne interpretovat' ich výsledky. Preto je nutné rozvíjat' kritické myslenie u študentov, a to práve rôznymi metódami, ako je napríklad brainstorming, round robin (metóda dookola), myšlienkové (pojmové) mapy a EUR (evokácia, uvedomenie, reflexia). Vel'mi zaujímavou metódou na rozvoj kritického myslenia je aj metóda „Kocka“, ktorá sa realizuje tak, že na každú stenu kocky sa napíše jedna z nasledujúcich 6 úloh: popíš, porovnaj, asociuj, analyzuj, aplikuj, argumentuj za a proti. Na hodine sa zadá téma, študenti hodia kockou a potom vykonávajú úlohu, ktorá im na kocke padne. Takto sa učia rozvíjat' kritické myslenie, svoje vyjadrovanie a postoj ku danej téme. Možno by stálo za zamyslenie, aby sa aj rodičia s det'mi, ale aj rovnocenní partneri (žiaci, študenti) medzi sebou hrali a robili cvičenia, aby sa zapájali do rozhovor a diskusií s úmyslom podporovat' kritické myslenie. Je dôležité naučit' sa počúvat' jeden druhého, vediet' argumentovat' a obhájit' si vlastný názor, naučit' sa čítat' s porozumením a v neposlednej miere ovládat' tvorbu grafov, či ich správne interpretovat'.

Táto práca bola podporovaná Agentúrou na podporu výskumu a vývoja na základe Zmluvy č. APVV-15-0368. Prácu podporila Kultúrna a vzdelávacia grantová agentúra (KEGA) Ministerstva školstva, vedy, výskumu a športu Slovenskej republiky na základe projektu číslo 044UKF-4/2017 s názvom „Modernizácia výučby a interdisciplinárneho prístupu v rámci kategórie odpad a odpadové hospodárstvo“.

\section{Bibliographic references}

CERETKOVA, S. a kol. 2017. Strategie tvoriveho a kritickeho myslenia v priprave ucitelov prirodovednych predmetov, matematiky a informatiky [elektronicky zdroj], Nitra : UKF, 2017. CD-ROM, 196 p. ISBN 978-80-5581231-1.

FESZTEROVA, M. 2015. Environmental Modeling - Alternatives and Use in Interdisciplinary Education. In: Acta Naturalis Scientia. ISSN 1339-5491. vol. 1, no. 2, pp. 1-6.

HORVATHOVA, D. - ZELENICKY, L. 2009. A note of hierarchical structure of information about the graph of function in the subject physics. In: Physics 2009 [elektronicky zdroj] : proceedings of Scientific Works. Nitra: SPU, pp. 1-7, ISBN 978-80-552-0264-8.

KONICKOVA, J. 2018. Metody kritickeho myslenia a ich vyuzitie v skole Available online: https://eduworld.sk/cd/jaroslava-konickova/2651/metodykritickeho-myslenia-a-ich-vyuzitie-v-skole 
KOSTURA POLK, R. E. 2018. Critical Thinking. In: The SAGE Encyclopedia of Educational Research, Measurement, and Evaluation, 2018. Thousand Oaks: SAGE Publications, Inc., pp. 429-432, ISBN 9781506326139.

KURZWEIL, J. 1985. O pojmu funkce ve skolske matematice $\mathrm{z}$ pohledu matematika. In: Zbornik ze seminare Terminologicke otazky skolske matematiky a fyziky. 1985. Praha: JCSMF, pp. 21-24.

TOMKOVA, V. - TIRPAKOVA, A. 2009. Graficke vyjadrovanie ziakov zakladnych skol v Slovenskej republike. In: Casopis Journal of Technology and information education. Olomouc : UP Olomouc, 2009. vol. 1, no 1. pp. 101-103. ISSN 1803537X.

TUREK, I. 2003. Kriticke myslenie. Prve vydanie. Bratislava: Metodickopedagogicke centrum, 70 p. ISBN 80-8052-175-1.

VELMOVSKA, K. 2012. Rozvijanie kritickeho myslenia ziakov pomocou strategie eur a jej aplikacia na vyucovanie fyziky. Available online: https://ufv.science.upjs.sk/_projekty/smolenice/pdf_14/37_velmovska.pdf

VRANAIOVA, K. 2014. Demokraticke obcianstvo v kazdodennej skolskej praxi. Prve vydanie. Bratislava: Metodicko-pedagogicke centrum, 62 p. ISBN 978-80-565-0376-8.

Radka Malá

Zita Jenisová

Department of Chemistry

Faculty of Natural Sciences

Constantine the Philosopher University in Nitra

Trieda A. Hlinku 1

94974 Nitra

Slovakia

radka.mala@ukf.sk

zjenisova@ukf.sk 